\title{
Pemanfaatan Berbagai Sumber Pupuk Kandang sebagai Sumber N dalam Budidaya Cabai Merah (Capsicum annum L.) di Tanah Berpasir
}

\author{
DOI 10.18196/pt.2014.032.125-132
}

\author{
Rendy Prasetyo \\ PT. Sinar Mas Agro Resouces and Technology, Plaza Sinar Mas Land, \\ Menara II, Lantai 30 Jl. MH Thamrin No. 51, Jakarta 10350 Telp. 62-21-50338899, Fax. 62-21-50389999, \\ email: rendy.prasetyo@gmail.com
}

\begin{abstract}
ABSTRAK
Penelitian bertujuan untuk mengkaji pemanfaatan berbagai sumber pupuk kandang sebagai sumber nitrogen dalam budidaya cabai merah. Penelitian dilaksanakan menggunakan metode percobaan yang disusun dalam Rancangan Acak Lengkap (RAL) yang terdiri atas 4 perlakuan yaitu 90 ton pupuk kandang sapi per hektar, 60 ton pupuk kandang kambing per hektar, 36 ton pupuk kandang ayam per hektar dan pupuk standar (1 ton NPK/hektar dan 20 ton pupuk kandang ayam/hektar). Hasil penelitian menunjukkan bahwa perlakuan pupuk kandang dan pupuk standar memberikan pengaruh yang tidak berbeda nyata kepada tinggi tanaman, berat segar buah dan diameter buah, tetapi memberikan pengaruh yang berbeda nyata kepada berat segar dan berat kering biomassa tanaman, jumlah buah per tanaman, panjang buah dan produksi buah cabai merah. Perlakuan 90 ton pupuk kandang sapi memberikan produksi cabai merah tertinggi yaitu 302,58 gram per tanaman, tetapi berbeda tidak nyata dengan perlakuan 36 ton pupuk kandang ayam per hektar. Kata kunci: Nitrogen, Tanaman cabai merah, Kandungan unsur hara, Pupuk kandang
\end{abstract}

\begin{abstract}
The aim of the research was to examine the effects of various sources of manure as a nitrogen sources on the cultivation of red chill. The experiment was conducted using experimental methods which are arranged in Complete Randomized Design (CRD) comprised 4 treatments, namely 90 ton of cow manure per hectare, 60 ton of goat manure per hectare, 36 ton of chicken manure per hectare and standard fertilizers (1 ton NPK/hectare and 20 tons of chicken manure/hectare). The results showed that treatment of manure and standards provide similar effects to the real plant height, weight fresh fruit and fruit diameter, but a significantly different effect on the weight of fresh and dry weight of plant biomass, number of fruits per plant, fruit lenght and production red chilies. Treatment of 90 tons of cow manure per hectare gave the bighest production of red chili that is 302.58 grams per plant, but did not differ significantly with treatment of 36 tons of chicken manure per hectare.

Keywords: Nitrogen, Red chili plant, Nutrient content, Manure
\end{abstract}

\section{PENDAHULUAN}

Cabai merah (Capsicum annuum L.) merupakan salah satu jenis sayuran yang memiliki nilai ekonomi yang tinggi. Cabai mengandung berbagai macam senyawa yang berguna bagi kesehatan manusia. Benidiktus (2010) melaporkan cabai mengandung antioksidan yang berfungsi untuk menjaga tubuh dari serangan radikal bebas. Selain itu Cabai juga mengandung Lasparaginase dan Capsaicin yang berperan sebagai zat anti kanker (BPPTP, 2008). Dengan begitu banyaknya manfaat dan kegunaan dari cabai merah menyebabkan permintaan cabai merah selalu meningkat sejalan dengan berkembangnya industri makanan baik dalam skala kecil, menengah, maupun skala besar yang memerlukan cabai merah sebagai bahan baku. Selain itu permintaan cabai merah segar guna memenuhi kebutuhan rumah tangga juga terus meningkat seiring dengan pertambahan jumlah penduduk di Indonesia.

Menurut Altieri (2000) dalam Nabila (2011), pupuk kimia anorganik secara temportelah meningkatkan hasil pertanian, tetapi keuntungan hasil panen akhirnya berkurang banyak dengan adanya penggunaan pupuk ini karena timbulnya degradasi (pencemaran) lingkungan pada lahan pertanian. Alasan utama kenapa pupuk anorganik menimbulkan pencemaran pada tanah 
karena dalam prakteknya banyak kandungan yang terbuang. Penggunaan pupuk kimia anorganik yang terus-menerus akan mempercepat habisnya zat-zat organik, merusak keseimbangan zat-zat makanan di dalam tanah, sehingga menimbulkan berbagai penyakit tanaman. Disamping itu harga dari pupuk anorganik dipasaran juga sangat mahal sehingga sangat memberatkan petani yang akhirnya berujung pada tingginya biaya produksi.

Pupuk organik sangat bermanfaat bagi peningkatan produksi pertanian baik kualitas maupun kuantitas, mengurangi pencemaran lingkungan, dan meningkatkan kualitas lahan secara berkelanjutan. Penggunaan pupuk organik dalam jangka panjang dapat meningkatkan produktivitas lahan dan dapat mencegah degradasi lahan. Disamping itu, dengan pemberian pupuk organik dalam jangka panjang mampu meningkatkan kandungan humus di dalam tanah. Dengan adanya humus tersebut air akan banyak terserap dan masuk ke dalam tanah, sehingga kemungkinan untuk terjadinya pengikisan tanah dan unsur hara yang ada di dalam tanah sangat kecil. Pupuk organik juga memiliki fungsi kimia yang penting seperti penyediaan hara makro (nitrogen, fosfor, kalium, kalsium, magnesium, dan sulfur) dan hara mikro seperti zink, tembaga, kobalt, barium, mangan, dan besi meskipun dalam jumlah yang kecil, meningkatkan kapasitas tukar kation tanah, dan membentuk senyawa kompleks dengan ion logam yang meracuni tanaman seperti aluminium, besi, dan mangan (Benny, 2010).

Jenis dari pupuk organik adalah pupuk kandang, pupuk kandang adalah pupuk yang berasal dari kotoran hewan. Hewan yang kotorannya sering digunakan untuk pupuk kandang adalah hewan yang bisa dipelihara oleh masyarakat, seperti kotoran sapi, kambing, dan ayam. Kandungan unsur hara dari ketiga jenis hewan ini pun berbeda-beda, sapi memiliki kandungan Nitrogen sebesar 0,4\%, Phospor 0,2\%, dan Kalium 0,1\%. Sedangkan kambing memiliki kandungan Nitrogen sebesar 0,6\%, Phospor 0,3\%, dan Kalium 0,17\%, serta ayam memiliki kandungan Nitrogen sebesar 1\%, Phospor 0,8\%, dan Kalium 0,4\%. Perbedaan kandungan unsur hara ini disebabkan oleh beberapa faktor yakni jenis hewan, jenis makanan yang diberikan serta umur dari ternak itu sendiri (Tohari, 2009).

Beberapa alasan dari penggunaan pupuk kandang yang berasal dari kotoran sapi, kambing dan ayam sebagai pengganti pupuk kimia dikarenakan bahannya mudah diperoleh, mempunyai kandungan unsur hara Nitrogen yang tinggi, dan merupakan jenis pupuk panas yang artinya adalah pupuk yang penguraiannya dilakukan oleh jasad renik tanah berjalan dengan cepat, sehingga unsur hara yang terkandung di dalam pupuk kandang tersebut dapat dengan cepat dimanfaatkan oleh tanaman dalam pertumbuhan dan perkembangannya.

Selain manfaat dari pupuk kandang, ketersedian bahan baku pupuk kandang (kotoran ternak) yang terus ada sangat memudahkan para petani untuk mendapatkannya. Menurut Dedi (2011), dalam sehari seekor sapi bisa menghasilkan kotoran sebanyak 5,5 kg dan dalam sebulan akan menghasilkan 165 kg. Sugiharto (2008) menyebutkan bahwa seekor kambing bisa menghasilkan $0,25 \mathrm{~kg} /$ hari atau $7,5 \mathrm{~kg} /$ bulan, sedangkan seekor ayam dalam sehari dapat menghasilkan 1,48 gr atau 0,45 kg/bulan. Selain bahan baku yang mudah didapat, harga dari pupuk kandang relative lebih murah dan terjangkau bagi kalangan petani.

Menurut Mariono, dkk (2012), penggunaan pupuk kandang ayam 14 ton/hektar bisa meningkatkan berat segar brangkasan tanaman cabai merah mencapai 389,20 g dan berat kering brangkasan mencapai 108,57 g. Sementara itu 
Sumarni et al. (2010) menyatakan bahwa pada takaran dosis pupuk kandang (pupuk kandang ayam dan sapi) yang sama yakni 20 ton/hektar pada jenis tanah Andisol, pertumbuhan dan hasil tanaman cabai merah yang diberikan pupuk kandang ayam lebih baik dibandingkan dengan pertumbuhan dan hasil dari tanaman cabai merah yang diberi pupuk kandang sapi.

Untuk itu perlu dilakukan penelitian terhadap jenis tanah yang berbeda yang dalam penelitian ini menggunakan jenis tanah berpasir dan menentukan jenis pupuk kandang yang terbaik bagi pertumbuhan dan hasil dari tanaman cabai merah pada jenis tanah berpasir. Penelitian ini bertujuan untuk mengkaji dan menetapkan sumber pupuk kandang sebagai sumber $\mathrm{N}$ yang terbaik bagi pertumbuhan dan hasil tanaman cabai merah, sehingga nantinya diharapkan penelitian ini dapat menjadi rekomendasi bagi para pertani cabai merah dalam memilih jenis pupuk kandang.

\section{BAHAN DAN METODE}

Penelitian dilakukan dengan metode percobaan yang disusun dalam Rancangan Acak Lengkap (RAL) faktor tunggal dengan 4 perlakuan, 3 perlakuan jenis pupuk kandang dan 1 pembanding yaitu 1 perlakuan standar menggunakan pupuk NPK dan pupuk kandang. Perlakuan yang dimaksud yaitu :

P1: Pupuk kandang Sapi 90ton/hektar

P2: Pupuk Kandang Kambing 60 ton/hektar P3: Pupuk Kandang Ayam 36 ton/hektar.

P4: NPK 1 ton/hektar + Pupuk Kandang Ayam 20 ton/hektar

Tiap perlakuan diulang sebanyak 8 kali untuk pengamatan pertumbuhan vegetatif berjumlah 32 polybag dan 8 kali untuk pengamatan hasil cabai merah berjumlah 32 polybag, sehingga total pengamatan 64 tanaman (pot).

Pot yang digunakan dalam penelitian ini adalah polybag berwarna hitam dengan tinggi 40 $\mathrm{cm}$ x $35 \mathrm{~cm}$ dan diameter $25 \mathrm{~cm}$. Untuk media tanam yang digunakan adalah campuran antara tanah + pupuk kandang dengan dosis pupuk sesuai perlakuan. Media tanam yang digunakan dalam penelitian ini adalah campuran antara tanah pekarangan dengan pupuk kandang. Perlakuan pupuk kandang diberikan sekaligus bersamaan dengan penyiapan media tanam, sedangkan perlakuan pupuk kimia NPK diberikan sebanyak 3 kali, yaitu pada saat penyiapan media tanam, 30 hari setelah tanam, dan 60 hari setelah tanam. Untuk perlakuan pupuk kandang tidak diberikan tambahan pupuk kimia.

Penyiraman dilakukan satu kali sehari yakni pada saat sore hari dengan takaran $500 \mathrm{ml}$. Perlakuan terhadap hama dan penyakit dilakukan dengan menyemprotkan insectisida dan fungisida yang dilakukan apabila terdapat tanda-tanda serangan hama dan penyakit.

Parameter pengamatan yang diukur terhadap tanaman cabai merah dalam pot yang telah diperlakukan dengan pupuk kandang sapi, kambing atau ayam yaitu:

1. Tinggi Tanaman $(\mathrm{cm})$

Mengukur tinggi tanaman dengan cara melakukan pengukuran tanaman mulai dari pangkal akar sampai ujung daun. Pengukuran dilakukan pada waktu tanaman cabai merah 20 hari setelah tanam, 40 hari setelah tanam, dan 60 hari setelah tanam dari masing-masing ulangan.

2. Berat segar biomassa tanaman (gram)

Penimbangan berat segar dilakukan pada umur 60 hari setelah tanam, dengan cara membongkar tanaman dari dalam polybag kemudian dibersihkan tanah yang masih menempel diakar dan ditimbang. 


\section{Berat kering biomassa tanaman (gram)}

Setelah melakukan penimbangan berat segar tanaman, lalu dikering anginkan selama 1 hari kemudian dilakukan pengovenan pada suhu $70{ }^{\circ} \mathrm{C}$ selama 5 jam. Setelah dikeluarkan lalu dimasukkan ke dalam desikator hingga dingin lalu ditimbang, kemudian dilakukan pengovenan kembali selama 1 jam dan ditimbang kembali hingga tercapai berat konstan.

4. Berat segar buah rata-rata (gram)

Pengukuran berat segar buah dilakukan dengan menimbang hasil panen dari masing-masing ulangan sampai masa panen kelima.

5. Jumlah buah tiap tanaman

Penghitungan jumlah buah dilakukan pada setiap batang tanaman cabai merah yang dihasilkan dari masing-masing ulangan dan dilakukan pada panen pertama sampai dengan panen kelima. Buah cabai yang diambil setelah 75\% berwarna merah.

\section{Panjang buah rata-rata $(\mathrm{cm})$}

Pengukuran panjang buah cabai dilakukan dengan cara mengukur tiap buah cabai hasil panen pada masa panen pertama sampai panen kelima.

7. Diameter buah rata-rata $(\mathrm{cm})$

Buah cabai yang telah diukur panjang buahnya, kemudian dilakukan pengukuran terhadap diameter buah rata-rata.

8. Produksi buah cabai (gram/pot)

Produksi buah cabai merah dalam pot diukur berdasarkan hasil tiap perlakuan yang dilakukan mulai masa panen pertama sampai panen kelima.

Data yang diperoleh dianalisis dengan sidik ragam RAL (Rancangan Acak Lengkap) dengan taraf kesalahan 5\%. Apabila terdapat beda nyata, maka analisis selanjutnya digunakan Uji Jarak Ganda Duncan (UJGD)5\% untuk menentukan pola tanggapan cabai merah terhadap pupuk kandang sapi, pupuk kandang kambing, dan pupuk kandang ayam.

\section{HASIL DAN PEMBAHASAN}

Pertumbuhan dan Perkembangan Tanaman

Tinggi tanaman merupakan salah satu parameter yang harus diamati untuk mengetahui pengaruh dari berbagai jenis pupuk tersebut terhadap pertumbuhan vegetatif tanaman cabai merah. Berdasarkan hasil sidik ragam 5\% terhadap tinggi tanaman pada umur perlakuan 60 hari setelah tanam tidak terdapat beda nyata antar perlakuan pemberian berbagai jenis pupuk kandang dan perlakuan campuran pupuk NPK + pupuk kandang ayam (Tabel 1).

Tabel 1. Rata-rata Tinggi Tanaman (cm), Berat Segar Tanaman (g), Berat Kering Tanaman

\begin{tabular}{|c|c|c|c|}
\hline Jenis Perlakuan & $\begin{array}{l}\text { Tinggi } \\
\text { Tanaman } \\
(\mathrm{cm})\end{array}$ & $\begin{array}{l}\text { Berat Segar } \\
\text { Tanaman } \\
\text { (g) }\end{array}$ & $\begin{array}{l}\text { Berat Kering } \\
\text { Tanaman } \\
(\mathrm{g})\end{array}$ \\
\hline Pupuk Kandang Sapi 90 ton/hektar & 100,250 & $212,28 a$ & 49,383 a \\
\hline Pupuk Kandang Kambing 60 ton/hektar & 88,938 & $148,26 b$ & $35,223 b$ \\
\hline Pupuk Kandang Ayam 36 ton/hektar & 91,688 & $177,64 a b$ & $39,130 \mathrm{~b}$ \\
\hline $\begin{array}{l}\text { Pupuk NPK } 1 \text { ton/hektar + Pupuk } \\
\text { Kandang Ayam } 20 \text { ton/hektar }\end{array}$ & 94,125 & $173,04 \mathrm{~b}$ & $41,569 a b$ \\
\hline
\end{tabular}

Grafik pertumbuhan tinggi tanaman cabai merah menunjukkan pertumbuhan tanaman mulai mengalami perbedaan tinggi tanaman pada hari ke-40, hal ini diduga adanya perbedaan kecepatan penyerapan unsur hara oleh tanaman (Gambar 1). Kecepatan penyerapan unsur hara dipengaruhi oleh kecepatan proses dekomposisi dari masing-masing jenis perlakuan pupuk kandang tersebut. Salah satu faktor yang mempengaruhi kecepatan proses dekomposisi adalah kelembapan dari bahan organik, proses dekomposisi dapat berlangsung pada kisaran kelembaban 30-100 \%, nilai kelembaban optimum pada 
proses dekomposisi berkisar antara 50-60\% dan dekomposisi akan berlangsung lambat pada kelembaban di bawah 40\% bobot (Gaur, 2013). Pupuk kandang sapi memiliki kandungan air yang lebih tinggi dibandingkan dengan jenis perlakuan pupuk kandang lainnya yakni $85 \%$ bobot sehingga tingkat kelembapan juga akan semakin tinggi, dengan tingkat kelembapan yang tinggi proses dekomposisi juga akan semakin cepat dan unsur hara yang terkandung pada pupuk kandang tersebut juga akan tersedia bagi tanaman sehingga unsur hara dapat terserap dan meningkatkan pertumbuhan tanaman.

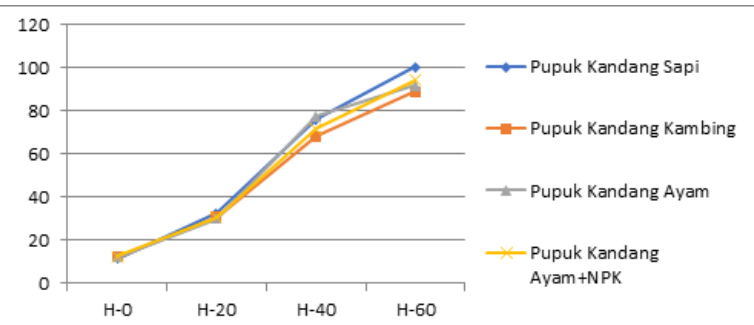

Gambar 1. Grafik Pertumbuhan Tinggi Tanaman Cabai Merah

Dengan semakin cepatnya unsur $\mathrm{N}$ dapat diserap oleh tanaman dalam suatu sumber pupuk organik maka pertumbuhan tinggi tanaman juga akan semakin baik. Selain berpengaruh pada tinggi tanaman, $\mathrm{N}$ juga sangat berperan pada pembentukan tunas, perkembangan batang dan daun yang nantinya juga akan mempengaruhi berat segar dan berat kering tanaman.

Berdasarkan hasil sidik ragam 5\% menunjukkan bahwa semua jenis perlakuan memberikan pengaruh yang berbeda terhadap berat segar biomassa tanaman (Tabel 1). Pemberian 90 ton/ hektar pupuk kandang sapi memiliki nilai berat segar biomassa tertinggi dibandingkan dengan jenis pupuk kandang lainnya, tetapi berat segar biomassa tanaman perlakuan pupuk kandang sapi berbeda tidak nyata dengan perlakuan 36 ton/hektar pupuk kandang ayam. Nilai berat segar biomassa tanaman yang diperlakuan pupuk kandang sapi lebih tinggi dibandigkan perlaukan lainya karena beberapa faktor seperti pengaruh kecepatan proses dekomposisi dari pupuk kandang dan ketersediaan air di dalam tanah yang digunakan sebagai media penyerapan unsur hara oleh tanaman.

Jamilah (2002) menyebutkan bahwa komposisi bahan organik yang terkandung pada kotoran sapi, kandungan serat organik yang berasal dari pakan tumbuh-tumbuhan pada hewan ternak seperti sapi menyebabkan proses dekomposisi bahan organiknya berlangsung dengan lambat sehingga unsur hara yang terkandung pada kotoran sapi bisa terserap secara perlahan selama proses pertumbuhan dan perkembangan tanaman. Sehingga selama proses pertumbuhan dan perkembangan berlangsung unsur hara yang dibutuhkan oleh tanaman akan terus tersedia.

Selain ketersediaan unsur $\mathrm{N}$ yang mencukupi, berat segar biomassa tanaman juga dipengaruhi oleh beberapa faktor eksternal dan faktor internal tanaman. Faktor eksternal seperti iklim (cahaya, suhu, air, panjang hari, angin dan gas), tanah (tekstur, struktur tanah, kandungan bahan organik, kapasitas pertukaran kation), dan biologis (gulma, serangga, organisme penyebab penyakit, macam-macam tipe herbivora, dan mikro organisme tanah). Sedangkan faktor internal yang mempengaruhi adalah ketahanan tanaman terhadap tekanan dari faktor eksternal, laju fotosintesis, respirasi, ketrsediaan klorofil, pembagian hasil asimilasi $\mathrm{N}$, kapasitas untuk menyimpan cadangan makanan, aktivitas enzim, pengaruh langsung dari gen tanaman itu sendiri, dan differensiasi (Rizky, 2010).

Berdasarkan hasil sidik ragam 5\% terhadap parameter berat kering biomassa tanaman terdapat beda nyata antar perlakuan pemberian 
berbagai jenis pupuk kandang dan perlakuan standar (pupuk NPK + pupuk kandang ayam). Berdasarkan data berat kering biomassa tanaman dalam tabel 1 dapat diketahui bahwa perlakuan 90 ton/hektar pupuk kandang sapi memberikan hasil berat kering biomassa tanaman tertinggi tetapi berbeda tidak nyata dengan perlakuan pemupukan pupuk NPK 1 ton/hektar + pupuk kandang ayam 20 ton/hektar, sedangkan perlakuan 60 ton/hektar pupuk kandang kambing tidak berbeda nyata dengan perlakuan 36 ton/hektar pupuk kandang ayam. Sedangkan perlakuan pupuk kandang sapi dan perlakuan pupuk standar berbeda nyata dengan perlakuan pupuk kandang kambing dan perlakuan pupuk kandang ayam.

Berat kering biomassa tanaman sangat dipengaruhi oleh proses pertumbuhan dan diferensiasi sel tanaman. Proses diferensiasi tanaman mempunyai tiga syarat yaitu hasil asimilasi yang tersedia dalam keadaan berlebihan untuk dapat dimanfaatkan pada kebanyakan kegiatan metabolik, temperatur yang menguntungkan, dan terdapat sistem enzim yang tepat untuk memperantarai proses diferensiasi. Apabila dari ketiga persyaratan tersebut dapat terpenuhi, maka akan terjadi penebalan dinding sel, deposit dari sebagian sel, pengerasan protoplasma (Franklin et al., 2008).

Pada vase vegetatif ini unsur $\mathrm{N}$ sangat dibutuhkan oleh tanaman untuk menunjang pertumbuhan dan perkembangan, perlakuan 90 ton/hektar pupuk kandang sapi telah terbukti mampu mensuplai kebutuhan $\mathrm{N}$ tanaman sehingga dapat dimanfaatkan selama vase vegetatif berlangsung. Unsur hara nitrogen sangat penting dalam proses pertumbuhan tanaman dan salah satu faktor yang mempengaruhi serapan unsur hara adalah proses dekomposisi bahan organik dan ketersediaan air, jika melihat kandungan unsur hara berbagai jenis pupuk kandang sudah tentu pupuk kandang ayam memiliki kandungan unsur hara lebih tinggi dibandingkan dengan pupuk kandang sapi.

\section{Hasil Produksi Tanaman}

Buah merupakan hasil akhir dari budidaya tanaman hortikultura. Sehingga berat segar buah sangat mempengaruhi hasil produksi tanaman. Tabel 2 menunjukkan bahwa uji sidik ragam terhadap berat segar buah rata-rata tidak ada beda nyata antar perlakuan berbagai jenis pupuk. Perlakuan masing-masing jenis pupuk dapat terserap dengan baik sehingga menghasilkan berat buah segar yang tidak berbeda nyata. Berat segar buah sangat dipengaruhi oleh dua hal yaitu kandungan air yang ada pada buah dan ketebalan daging buah tersebut.

Tabel 2. Rata-rata berat segar buah rata-rata (g)

\begin{tabular}{lccc}
\hline \multicolumn{1}{c}{ Jenis Perlakuan } & $\begin{array}{c}\text { Berat Segar } \\
\text { Buah (g) }\end{array}$ & $\begin{array}{c}\text { Jumlah } \\
\text { Buah }\end{array}$ & $\begin{array}{c}\text { Potensi Hasil } \\
\text { (g/pot) }\end{array}$ \\
\hline Pupuk Kandang Sapi 90 ton/hektar & 2,463 & $45,500 \mathrm{a}$ & $302,58 \mathrm{a}$ \\
Pupuk Kandang Kambing 60 ton/hektar & 2,341 & $32,125 \mathrm{~b}$ & $252,85 \mathrm{bc}$ \\
Pupuk Kandang Ayam 36 ton/hektar & 2,392 & $28,375 \mathrm{~b}$ & $265,87 \mathrm{ab}$ \\
$\begin{array}{l}\text { Pupuk NPK 1 ton/hektar + Pupuk } \\
\text { Kandang Ayam 20 ton/hektar }\end{array}$ & 2,299 & $24,625 \mathrm{~b}$ & $218,85 \mathrm{c}$ \\
\hline
\end{tabular}

Keterangan: Angka rerata yang diikuti oleh huruf yang sama menunjukan tidak berbeda nyata menurut uji jarak ganda Duncan $5 \%$.

Menurut Harjadi (1979) dalam Nurjannah, dkk.(2013), bahwa pembentukan dan pengisian buah sangat dipengaruhi oleh unsur hara $(\mathrm{N}$, $\mathrm{P}$ dan $\mathrm{K}$ ) yang akan digunakan dalam proses fotosintesis yaitu sebagai penyusun karbohidrat, lemak, protein, mineral dan vitamin yang akan ditranslokasikan kebagian penyimpanan buah. Ditambahkan oleh Suprihartini (1995) dalam Nurjannah, dkk.(2013), bahwa untuk perkembangan buah sangat dipengaruhi oleh pembentukan auksin pada biji-biji yang sedang berkembang dan bagian-bagian lain pada buah yang berfungsi untuk menyuplai cadangan makanan 
guna meningkakan perkembangan buah. Penambahan bahan organik telah terbukti memperbaiki tanah baik secara fisik, biologis, dan kimiawi tanah.

Penghitungan jumlah buat tiap tanaman juga penting untuk dilakukan, kriteria penghitungan buah yang dilakukan apabila buah tersebut telah mengalami tingkat kemerahan atau kematangan sebanyak $75 \%$. Berdasarkan hasil sidik ragam 5\% menunjukkan bahwa semua perlakuan memberikan pengaruh yang berbeda terhadap jumlah buah tiap tanaman (Tabel 2). Perlakuan 90 ton/hektar pupuk kandang sapi memberikan hasil yang signifikan terhadap jumlah buah per tanaman, hal ini dikarenakan perlakuan 90 ton/ hektar pupuk kandang sapi memberikan suplai $\mathrm{P}$ dan $\mathrm{K}$ yang lebih tinggi bagi tanaman cabai merah sehingga dapat meningkatkan hasil cabai merah. Disamping itu dengan penambahan 90 ton/hektar pupuk kandang sapi diduga lebih baik dalam memperbaiki struktur tanah dan kadar lengas tanah sehingga tanah mampu menjaga ketersediaan air lebih baik dibandingkan dengan perlakuan lainnya. Unsur hara nitrogen yang terkandung pada pupuk kandang sapi berperan penting dalam pembentukan zat hijau daun yang digunakan dalam proses fotosintesis tanaman yang menghasilkan karbohidrat sebagai makanan yang akan digunakan dalam proses pertumbuhan.

Pemberian nitrogen yang cukup selain berguna dalam masa pertumbuhan tanaman juga berguna dalam perkembangan mikroorganisme dalam tanah. Kandungan air pada pupuk kandang sapi yang lebih tinggi dibandingkan dengan pupuk kandang lainnya memudahkan kandungan nitrogen yang tersedia pada pupuk kandang sapi mudah terserap oleh tanah dan tanaman sehingga perkembangan mikroorganisme dalam tanah juga akan semakin baik. Dengan ban- yaknya mikroorganisme dalam tanah maka akan membantu tersedianya unsur hara esensial lainnya yang dibutuhkan dalam proses pembuahan tanaman.

Berdasarkan hasil uji jarak berganda Duncan 5\% diketahui perlakuan pupuk kandang sapi berbeda nyata dengan perlakuan pupuk kandang kambing serta perlakuan pupuk standar (pupuk NPK + pupuk kandang ayam), sedangkan pupuk kandang ayam tidak berbeda nyata dengan perlakuan pupuk kandang kambing dan berbeda nyata dengan perlakuan pupuk standar (pupukNPK + pupuk kandang ayam) terhadap potensi hasil buah cabai. Hal ini membuktikan bahwa unsur hara 90 ton/hektar pupuk kandang sapi lebih cepat terserap oleh tanaman dibandingkan dengan jenis pupuk kandang lainnya, pupuk kandang sapi memiliki kemampuan menahan air lebih tinggi dibandingkan dengan jenis pupuk kandang lainnya sehingga unsur hara yang ada pada pupuk kandang sapi dapat terserap dengan baik oleh tanaman. Selain kemampuan menampung ketersediaan air, hal yang berpengaruh lainnya pada serapan unsur hara pupuk kandang sapi adalah masa dekomposisi bahan organik dari pupuk kandang itu sendiri. Dengan banyaknya serat organik tanaman yang terkandung pada kotoran sapi menyebabkan masa dekomposisi lebih panjang dibandingkan dengan jenis pupuk kandang lainnya sehingga unsur hara yang dibutuhkan oleh tanaman dapat tersedia. Menurut Franklin, et al. (2008) terserapnya unsur nitrogen yang terkandung pada pupuk kandang sapi dengan baik menyebabkan pertumbuhan daun tanaman cabai menjadi semakin baik sehingga fotosintesis dapat berlangsung dengan baik tentunya didukung dengan kecukupan air, karbondioksida, klorofil yang dihasilkan oleh daun dan tentunya sinar matahari. Nutrisi yang cukup terutama nitrogen akan menyebab- 
kan pertumbuhan tanaman dan perkembangan tanaman berlangsung dengan baik. Selain unsur nitrogen, pada pupuk kandang sapi juga tersedia unsur fosfor yang dibutuhkan tanaman untuk mempercepat proses pembungaan. Tidak terbantahkan bahwa dengan banyaknya bunga tidak berarti akan menghasilkan banyak buah, tetapi dengan banyaknya bunga setidaknya proses pembuahan akan mengalami keberhasilan yang tinggi.

\section{SIMPULAN}

Perlakuan pupuk kandang dan pupuk standar memberikan pengaruh yang tidak berbeda nyata terhadap tinggi tanaman, berat segar buah rata-rata, dan diameter buah rata-rata, tetapi memberikan pengaruh yang berbeda nyata terhadap berat segar biomassa tanaman, berat kering biomassa tanaman, jumlah buah tiap tanaman, panjang buah rata-rata, dan produksi buah cabai merah per tanaman. Perlakuan 90 ton/hektar pupuk kandang sapi memberikan produksi buah tertinggi yaitu 302,58 g/tanaman tetapi berbeda tidaknyata dengan perlakuan 36 ton/hektar pupuk kandang ayam.

Perlu dilakukan penelitian lebih lanjut mengenai dosis pupuk kandang sapi untuk meminimalkan penggunaan pupuk an-organik sehingga pupuk kandang sapi yangdigunakan bisa lebih efisien, hal ini perlu dilakukan karena akan berimbas langsung terhadap biaya produksi yang akan dikeluarkan oleh petani.

\section{DAFTAR PUSTAKA}

Balai Besar Pengkajian dan Pengembangan Teknologi Pertanian. 2008. Teknologi Budidaya Cabai Merah. http://lampung. litbang.deptan.go.id/ind/images/stories/publikasi/teknologibudidayacabai.pdf. Diakses Pada 2 Maret 2012.

Benidiktus, S. 2010. Cabe. http://www.ideelok.com/budidayatanaman/cabe. Diakses Pada 7 Maret 2012.

Benny N Joewono. 2010. Pupuk Kandang. http://nasional.kompas. com/read/2010/11/26/20241199/tahi.ayam.ini.harganya. rp.500 . Diakses Pada 4 Juni 2012.
Dedi. 2011. Analisa Usaha Budidaya Ternak Sapi Potong. http:// epetani.deptan.go.id/budidaya/analisa-usaha-budidaya-ternak-sapi-potong-1726. Diakses Pada 4 Juni 2012.

Franklin P.G., R. Brent P., Roger L.M. 2008. Fisiologi Tanaman Budidaya. Penerbit Universitas Indonesia (UI Press). Jakarta.

Gaur. 2012. http://repository.ipb.ac.id/bitstream/handle/123456789/1369/BAB\%20I\%20TINJAUAN\%2OPUSTAKA.pdf?sequence=7. Diakses Pada 11 mei 2013.

Jamilah, SP. MP. 2002. Pengaruh Pemberian Pupuk Kandang Dan Kelengasan Terhadap Perubahan Bahan Organik Dan Nitrogen Total Entisol. Universitas Sumatera Utara.http://repository.usu.ac.id/bitstream/123456789/1133/1/tanah-jamilah. pdf. Diakses Pada 12 Juni 2012.

Mariono, Endang S, dan Tyas SKD. 2012. Pengaruh Macam Varietas dan Dosis Pupuk OrganikPadat Terhadap Pertumbuhan dan Hasil Tanaman Cabai Merah.http://ejournal.utp.ac.id/ index.php/AFP/article/view/8/7. Diakses Pada 8 Juni 2012.

Nabila, N.S. 2012. Pencemaran Tanah Oleh Pupuk. http://ilmuwanmuda.wordpress.com/pencemaran-tanah-oleh-pupuk/. Diakses Pada 2 Maret 2012.

Nurjannah Ifatrul Yani, dkk. 2013. Pengaruh Beberapa Jenis Pupuk Kandang Terhadap Pertumbuhan Dan Hasil Tanaman Cabai Merah Pada Tanah Gambut. http://webcache.googleusercontent.com/search?q=cache:GyNHA1 wVad0]:jurnal. untan.ac.id/index.php/jspp/article/view/1185/1199+\&cd=1\& $\mathrm{hl}=\mathrm{en} \& \mathrm{ct}=\mathrm{clnk} \& \mathrm{client}=$ firefox-a. Diakses Pada 13 Juni 2013.

Rizky Bayo. D. 2010. http://catatanbayodongoran.blogspot. com/2010/10/perkecambahan-tujuan-untuk-mempelajari. html. Diakses Pada 11 Mei 2013

Sumarni, N., R. Rosliani, dan A.S. Duriat. 2010. Pengelolaan Fisik, Kimia, dan Biologi Tanah Untuk Meningkatkan kesuburan Lahan dan Hasil Cabai merah. Balai penelitian Tanaman Sayuran.

Tohari, Y. 2009. Kandungan Hara Pupuk Kandang. http://tohariyusuf.wordpress.com/2009/04/25/kandungan-hara-pupukkandang/. Diakses Pada 29 feburari 2012.

Sugiharto Toto. 2008. Analisa Usaha Kambing Etawa. http:// www.gunungkelir.com/analisa-usaha-kambing-etawa/. Diakses Pada 4 Juni 2012. 